\title{
The Tower of Babel: A Case Study in the Competing Methods of Historical and Modern Literary Criticism
}

\author{
JOEL S. BADEN \\ joel.baden@yale.edu \\ Yale Divinity School, New Haven, CT 06511
}

Since the rise of modern literary criticism of the Hebrew Bible in the 1970s, its proponents have sought to use the results of this method to argue for the compositional unity of the biblical text, particularly in regard to the Pentateuch. They have held up the literary structures they find in the text-alliteration, repetition, and other forms of wordplay, as well as larger structures such as chiasm-as proof of a conscious artistry on the part of the biblical author, an artistry that, in their opinion, belies any attempt to separate the text into constituent documents or layers. That these literary observations are useful in reading the final form of the text is hardly in question; but whether they are, in fact, an effective means of countering the results of historical criticism remains in doubt. In this article I will address this very issue by means of a detailed examination of a particular passage, the Tower of Babel narrative, and the ways in which modern literary critics have attempted to prove its unity. The results of this case study will lead to a discussion of the relationship between the two methods of modern literary criticism and historical criticism.

In his commentary on Genesis, Hermann Gunkel proposed a novel analysis of the Tower of Babel narrative in Gen 11:1-9. ${ }^{1}$ He argued that this brief story actually comprises two originally independent recensions: one about the building of a tower, and one about the building of a city; the first explaining the dispersion of humanity, the second the confusion of languages. This analysis was intended to resolve what Gunkel considered to be inconsistencies in the narrative: the appar-

${ }^{1}$ Hermann Gunkel, Genesis (3rd ed., 1910; trans. Mark E. Biddle; Macon, GA: Mercer University Press, 1997), 94-102.

This article was published in JBL 128/2 (2009) 209-24, copyright (־ 2009 by the Society of Biblical Literature. To purchase copies of this issue or to subscribe to JBL, please contact SBL Customer Service by phone at 866-727-9955 [toll-free in North America] or 404-727-9498, by fax at 404-727-2419, or visit the online SBL Store at www.sbl-site.org. 
ent double mention of brick-making in v. 3; the double descent of God in vv. 5 and 7 ; and the alternation between city and tower, language and location. His two recensions are as follows: ${ }^{2}$

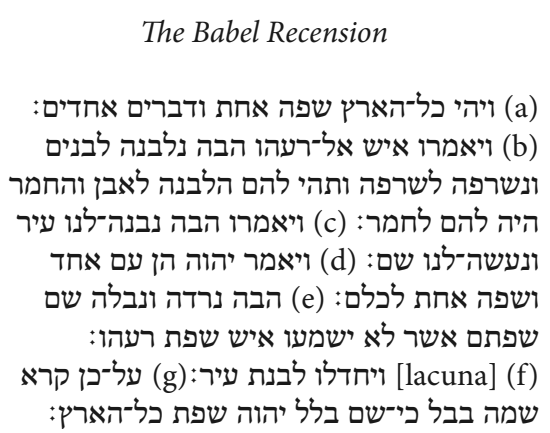

(a) All the earth had the same language and the same words. (b) Each said to his neighbor, "Come, let us build bricks and burn them." They had brick for stone and bitumen for mortar. (c) They said, "Come, let us build a city and make a name for ourselves." (d) Yнwн said, "Look, it is one people, and one language for all of them. (e) Let us go down and confuse their speech there, so that each will not understand the language of his neighbor." ... (f) They ceased building the city. (g) Therefore it was called Babel, because there Yнwн confused the language of all the earth.

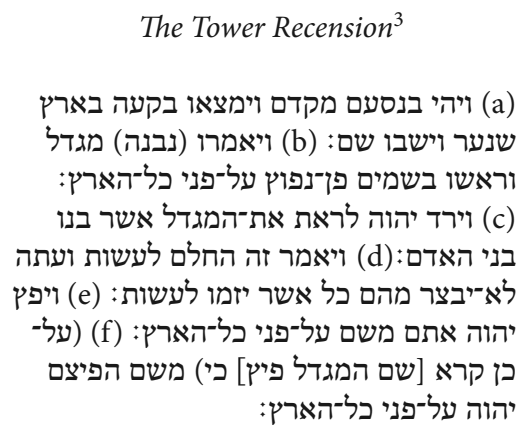

The Tower Recension ${ }^{3}$

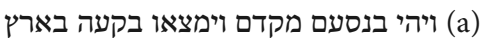

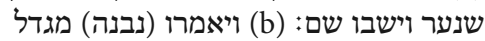

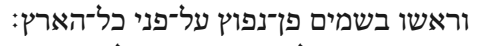

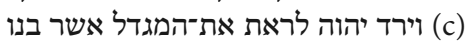

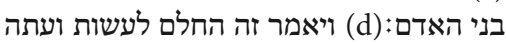

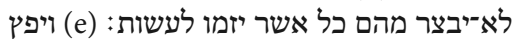

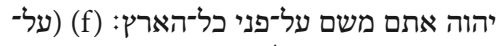

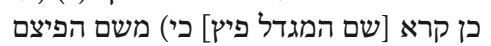
יהוה על־פני כל־־ארץ

(a) When they traveled from the east, they found a valley in the land of Shinar and settled there. (b) They said, "(Let us build) a tower, with its head in the heavens, lest we be scattered over the face of all the earth." (c) YHwH came down to see the tower that the humans had built. (d) He said, "This is the beginning of their acting; nothing that they propose to do will be withheld from them." (e) Yнwн scattered them from there over the face of all the earth. (f) (Therefore [the tower was called Pitz,] because) from there Yнwн scattered them over the face of all the earth.

With the prominent exception of John Skinner, Gunkel's suggestion found little acceptance in the mainstream of critical scholarship, with most commentaries simply assuming the unity of passage. ${ }^{4}$ Only recently has there been a renewed

${ }^{2}$ I have taken the liberty of making one change to Gunkel's analysis, by reuniting the two halves of v. 3 ; it is clear that v. 3 b is explanatory to v. 3 a, rather than a doublet thereof. See P. J. Harland, “The Sin of Babel: Vertical or Horizontal?” VT 48 (1998): 515-33, here 517.

${ }^{3}$ Text in parentheses indicates reconstruction based on the parallels in the Babel Recension; text in square brackets indicates Gunkel's invention.

${ }^{4}$ John Skinner, A Critical and Exegetical Commentary on Genesis (2nd ed.; ICC; Edinburgh: T\&T Clark, 1930), 223-24. Cuthbert A. Simpson (The Early Traditions of Israel [Oxford: Basil Blackwell, 1948], 67-68) saw here not two parallel strands, but an original J narrative and a redac-

This article was published in JBL 128/2 (2009) 209-24, copyright @ 2009 by the Society of Biblical Literature. To purchase copies of this issue or to subscribe to JBL, please contact SBL Customer Service by phone at 866-727-9955 [toll-free in North America] or 404-727-9498, by fax at 404-727-2419, or visit the online SBL Store at www.sbl-site.org. 
attempt to argue against the unity of the tower of Babel narrative, notably by Christoph Uehlinger in his monograph on the subject. ${ }^{5}$ Yet this attempt, like that of Gunkel, has found little support; a review by Ronald Hendel and an article by P. J. Harland have both effectively countered Uehlinger's argument. ${ }^{6}$ The focus of this study, however, is specifically Gunkel's source-critical breakdown of the text and the method of those who rejected his proposal. The major counterarguments to Gunkel, whether explicit or implicit, have come almost exclusively from the ranks of the modern literary critics. The first significant blow was struck by Umberto Cassuto in his commentary on Genesis; he was followed by Isaac Kikawada, in a paper entitled “The Shape of Genesis 11:1-9," and Jan P. Fokkelman, in his Narrative Art in Genesis. ${ }^{7}$ These scholars have gone to great lengths in arguing for the unity of this pericope by demonstrating that it contains wordplay, alliteration, chiastic structure, and other literary features. These features, it is claimed, prove that these nine verses are the product of a single artistic mind and must therefore be considered a unified text.

Cassuto said of Gunkel's recensions, "It is unnecessary to enter into elaborate arguments in order to show that no intelligent Hebrew writer would have produced such insipid texts ... after pointing out ... the beauty and harmonious structure of the story in its present form, it is perhaps superfluous to examine in detail the reasons advanced for partitioning it between two sources." ${ }^{8}$ Cassuto began by examining what he called the "constantly recurring melody" of the letters bet, lamed, להם ,הבה נלבנה לבנים and לה

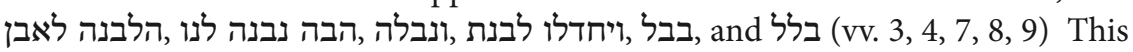
impressive collection is indeed difficult to explain as mere chance. Yet all of these words and phrases occur in Gunkel's Babel Recension ([b], [c], [e], [f], [g]). The only similar word in the Tower Recension is the reconstructed נבנה in (b).

tional overworking. On the relatively sparse scholarship that dealt with Gunkel's theory, see Claus Westermann, Genesis 1-11 (CC; Minneapolis: Fortress, 1994), 536-37.

${ }^{5}$ Christoph Uehlinger, Weltreich und "eine Rede": Eine neue Deutung der sogenannten Turmbauerzählung (Gen 11, 1-9) (OBO; Freiburg: Universitätsverlag, 1990). See also Klaus Seybold, "Der Turmbau zu Babel: Zur Entstehung von Genesis XI 1-9," VT 26 (1976): 453-79; and most recently Christian Rose, "Nochmals: Der Turmbau zu Babel," VT 54 (2004): 223-38.

${ }^{6}$ Ronald S. Hendel, review of Christoph Uehlinger, Weltreich und "eine Rede," CBQ 55 (1993): 785-87; Harland, "Sin," 517-19. Their objections respond effectively also to the arguments of Seybold and Rose (see previous note).

${ }^{7}$ Umberto Cassuto, A Commentary on the Book of Genesis, vol. 2, From Noah to Abraham (trans. Israel Abrahams; 1964; repr., Jerusalem: Magnes, 1992); Isaac Kikawada, "The Shape of Genesis 11:1-9," in Rhetorical Criticism: Essays in Honor of James Muilenburg (ed. Jared J. Jackson and Martin Kessler; PTMS 1; Pittsburgh: Pickwick, 1974), 18-32; Jan P. Fokkelman, Narrative Art in Genesis: Specimens of Stylistic and Structural Analysis (2nd ed.; Sheffield: JSOT Press, 1991), $11-45$.

${ }^{8}$ Cassuto, Genesis, 236.

${ }^{9}$ Ibid., $232-33$.

This article was published in JBL 128/2 (2009) 209-24, copyright @ 2009 by the Society of Biblical Literature. To purchase copies of this issue or to subscribe to JBL, please contact SBL Customer Service by phone at 866-727-9955 [toll-free in North America] or 404-727-9498, by fax at 404-727-2419, or visit the online SBL Store at www.sbl-site.org. 
Cassuto cited two examples of paronomasia: נלבנה לבנים, and ונשרפה לשרפה (v. 3). ${ }^{10}$ Both are in the Babel Recension ([b]). He cleverly suggested a relationship between the verb פוץ (vv. 4, 8, 9) and the phrase 4, 8, 9), "whose initial and final letters constitute the chief consonants of the verb."11 This wordplay, if accepted, is nevertheless entirely located in the Tower Recension ([b], [e], [f]). He pointed also to the alliterative phrases הלבנה לאבן and והחמר היה להם לחמר (v. 3). ${ }^{12}$ These are undoubtedly examples of literary art; both are in the Babel Recension $([\mathrm{b}])$.

Cassuto noted the repetition of various words and phrases throughout the text: שפה, which occurs five times (vv. 1, 6, 7 [2x], 9)-all in the Babel Recension -and כל־הארץ, which also occurs five times (vv. 1, 4, 8, 9 [2x]). ${ }^{13}$ But we can be more precise: twice it appears simply as כל־ כליהארץ (vv. 1, 9), and three times in the phrase על־פני כל־הארץ occurs in the first and last lines of the Babel Recension ([a], [g]), forming a beautiful inclusio. The phrase occurs exclusively in the Tower Recension ([b], [e], [f]). Note also that in the Babel Recension, כל־־ארץ refers to the people; in the Tower Recension, it refers to the land. Cassuto's final proof of the unity of the narrative is the seven-

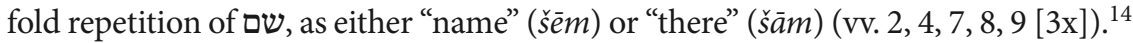
Cassuto, here and elsewhere, pointed to the significance of the number 7 , calling it earlier in his commentary "the golden thread that binds together all the parts ... and serves as a convincing proof of unity." 15 If we break up the narrative into two recensions, we destroy this sevenfold repetition. We are left, however, with two distinct uses of the word in the two proposed recensions. The real meat of the wordplay with שם is found only in the Babel Recension, where the people are concerned about making a name for themselves; there we find še $\bar{e} m$ twice $([\mathrm{c}],[\mathrm{g}])$ and $s \bar{a} m$ twice ([e], [g]). In the Tower Recension, there is but one šem ([f]). There are three occurrences of šäm, however, and they occur only in the verses relating to the settling in and dispersal from Shinar ([a], [e], [f]). This, it can be argued, is a fine example of narrative artistry, in which the keyword šam guides the reader to the great reversal in the story. This is perhaps even more the case if we include, as Cassuto did not, the word שמים ([b]).

It seems, then, that virtually every example of literary art that Cassuto adduced to demonstrate the unity of the text can be just as easily brought to demonstrate the literary art of the individual recensions. This would seem to be a major blow to Cassuto's rejection of Gunkel's theory. In order to use these wordplays and alliterations to prove textual unity, one has to show that in dividing the text the wordplay

${ }^{10}$ Ibid., 234.

${ }^{11}$ Ibid.

${ }^{12}$ Ibid.

${ }^{13} \mathrm{Ibid}$.

${ }^{14}$ Ibid.

${ }^{15}$ Umberto Cassuto, A Commentary on the Book of Genesis, vol. 1, From Adam to Noah (trans. Israel Abrahams; 1961; repr., Jerusalem: Magnes, 1998), 15.

This article was published in JBL 128/2 (2009) 209-24, copyright @ 2009 by the Society of Biblical Literature. To purchase copies of this issue or to subscribe to JBL, please contact SBL Customer Service by phone at 866-727-9955 [toll-free in North America] or 404-727-9498, by fax at 404-727-2419, or visit the online SBL Store at www.sbl-site.org. 
is lost, or the alliteration broken up between the two recensions. In short, at least in terms of the types of analysis used by Cassuto, we can argue that the Babel Recension and the Tower Recension each contain distinct and varied examples of literary art. When they were combined, the art was retained — but in almost no case can it be said to have been improved.

The work of Kikawada and Fokkelman is of a different nature from that of Cassuto. Whereas Cassuto dealt mainly in individual words, phrases, and even consonants, in repetition, alliteration, and wordplay, Kikawada and Fokkelman deal mainly with the larger structures of the text. ${ }^{16}$ Kikawada describes the overarching plot structure of the story first in terms of content: vv. 1-4 describe humanity's intentions and actions; v. 5, the axis of the story, is God's descent; and vv. 6-9 describe God's intentions and actions. ${ }^{17}$ Structurally, this is very sound; so, however, are the recensions. Note the structure of the Babel Recension:

(a) the general situation

(b)-(c) humanity's intentions

(d)-(e) God's intentions

(f) the result of the interface between humanity's and God's intentions (g) the new general situation

Unlike Kikawada's analysis of the unified text, the Babel Recension does not exhibit a chiastic structure. It seems evident, however, that the structure exhibited in the Babel Recension is just as artistically valid (chiasm, after all, was not the sole narrative structure available to the biblical authors ${ }^{18}$ ); it could certainly be supposed that this structure is intentional, designed to propel the story toward its etiological conclusion. One could, with little difficulty, make a serious argument for the theological meaning inherent in this structure.

If a chiasm is desired, however, the Tower Recension provides one:

(a) description of humanity's movement

(b) humanity's actions

(c-d) God's response

(e) God's actions

(f) description of humanity's movement

${ }^{16}$ Fokkelman also notes many of the verbal features already pointed out by Cassuto. For a critical examination of Fokkelman's study of Gen 11:1-9, see Yitshak Avishur, Studies in Biblical Narrative: Style, Structure, and the Ancient Near Eastern Literary Background (Tel Aviv-Jaffa: Archaeological Center Publication, 1999), 282-88.

${ }^{17}$ Kikawada, "Shape," 19 . This structure is not explicitly noted by Kikawada, but is evident in his structural outline of the text. He refines this analysis somewhat, following Radday, in Isaac Kikawada and Arthur Quinn, Before Abraham Was: The Unity of Genesis 1-11 (San Francisco: Ignatius, 1989), 73-74.

${ }^{18}$ For an argument against chiasmus as a significant aspect of biblical style in general, see David P. Wright, "The Fallacies of Chiasmus: A Critique of Structures Proposed for the Covenant Collection (Exodus 20:23-23:19)," ZABR 10 (2004): 143-68, esp. 143 n. 2.

This article was published in JBL 128/2 (2009) 209-24, copyright @ 2009 by the Society of Biblical Literature. To purchase copies of this issue or to subscribe to JBL, please contact SBL Customer Service by phone at 866-727-9955 [toll-free in North America] or 404-727-9498, by fax at 404-727-2419, or visit the online SBL Store at www.sbl-site.org. 
Again, there would be no difficulty in finding theological meaning in this structure.

Kikawada further states: "If we note such grammatical categories as indirect and direct discourse, we discover an identical distribution of quantitative balance, with respect to narrative character." ${ }^{\prime 9}$ This can be displayed as follows:

vv. 1-2: indirect discourse

vv. 3-4: direct discourse

v. 5: indirect discourse

vv. 6-7: direct discourse

vv. 8-9: indirect discourse

But the same distribution is found in both recensions individually. In the Babel Recension:

(a) indirect discourse

(b-e) direct discourse

$(\mathrm{f}-\mathrm{g})$ indirect discourse

In the Tower Recension we find an even fuller chiasm:

(a) indirect discourse

(b) direct discourse

(c) indirect discourse

(d) direct discourse

(e-f) indirect discourse $\mathrm{e}^{20}$

Kikawada, like Cassuto, provides arguments for unity that can be equally applied to Gunkel's individual recensions. ${ }^{21}$

Fokkelman, for his part, finds in the text both parallel symmetry and concentric symmetry. He lays out the parallel symmetry of the unified text as follows: ${ }^{22}$

${ }^{19}$ Kikawada, "Shape," 20.

${ }^{20}$ Kikawada's distribution is perhaps more aesthetically pleasing, insofar as the nine verses of the story are divided up into vv. 1-2, 3-4, 5, 6-7, and 8-9, whereas the Tower Recension, at least, comes out as (a), (b), (c), (d), and (e-f). But this serves to highlight a more general problem with Kikawada's entire structural analysis: it is apparently based primarily on the verse divisions in the text. Given that the versification of the biblical text was a relatively late development, however, it is illegitimate to use the verse as a meaningful textual unit when doing any sort of analysis, including modern literary criticism.

${ }^{21}$ One might even say that it is remarkable that these two recensions, which have, after all, different structural features, could have been combined in such a way that they create an entirely new structural pattern. This, however, falls under the category of redaction criticism.

${ }^{22}$ Fokkelman, Narrative Art, 20.

This article was published in JBL 128/2 (2009) 209-24, copyright (־ 2009 by the Society of Biblical Literature. To purchase copies of this issue or to subscribe to JBL, please contact SBL Customer Service by phone at 866-727-9955 [toll-free in North America] or 404-727-9498, by fax at 404-727-2419, or visit the online SBL Store at www.sbl-site.org. 


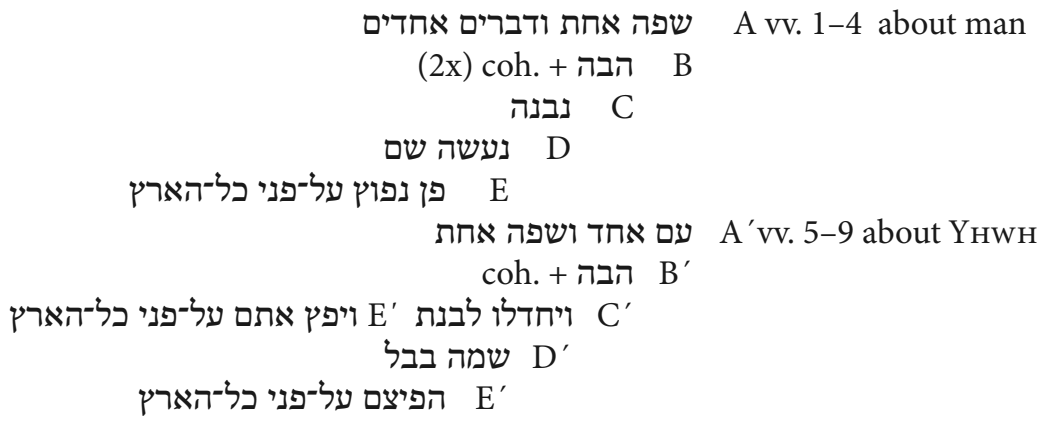

On first glance, this analysis looks promising; upon closer inspection, however, there are some difficulties. Even within Fokkelman's own layout, the element labeled $\mathrm{E}^{\prime}$ is out of place. ${ }^{23}$ Furthermore, and perhaps more critically, this analysis takes into account only those elements that fit it; undoubtedly the words and phrases Fokkelman has selected for inclusion work within the structure he has suggested, but the rest of the narrative is left aside. ${ }^{24}$ Accepting Fokkelman's structural analysis for the time being, however, we may turn to Gunkel's recensions and ask whether they, too, demonstrate parallel symmetry, using precisely the same elements as Fokkelman. In doing so, we find that, in the Babel Recension at least, the parallel symmetry is maintained:

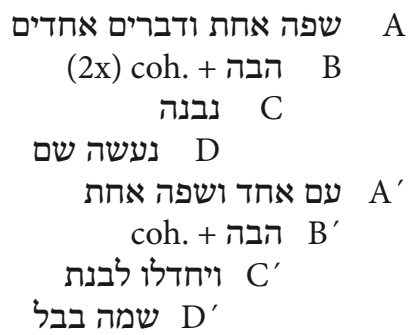

Furthermore, the difficulty of the misplaced E' element of Fokkelman's analysis is removed. As for the Tower Recension, one would be hard-pressed to call this parallel symmetry:

${ }^{23}$ David P. Wright has labeled this phenomenon "chiastic interference" (Marc Z. Brettler, The Book of Judges [Old Testament Readings; London: Routledge, 2002], 118 n. 6).

${ }^{24}$ It is thus somewhat problematic for Fokkelman to claim that "the objectivity of this parallelism of series of words precedes all interpretation, so much so that any reader, not knowing Hebrew but with a transcription of the story at his disposal, can be shown that the members of the series correspond because of the identity of words and he can inspect their order" (Narrative Art, 21).

This article was published in JBL 128/2 (2009) 209-24, copyright @ 2009 by the Society of Biblical Literature. To purchase copies of this issue or to subscribe to JBL, please contact SBL Customer Service by phone at 866-727-9955 [toll-free in North America] or 404-727-9498, by fax at 404-727-2419, or visit the online SBL Store at www.sbl-site.org. 


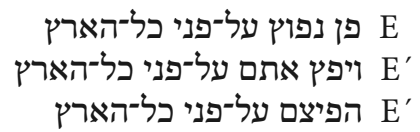

This is simply repetition, which should, of course, not be dismissed as stylistically void; rather, it would surely be considered a feature of the literary artistry of the proposed narrative. But the parallel symmetry that Fokkelman describes is really found only in the Babel Recension.

Fokkelman finds concentric symmetry in the text as follows: ${ }^{25}$

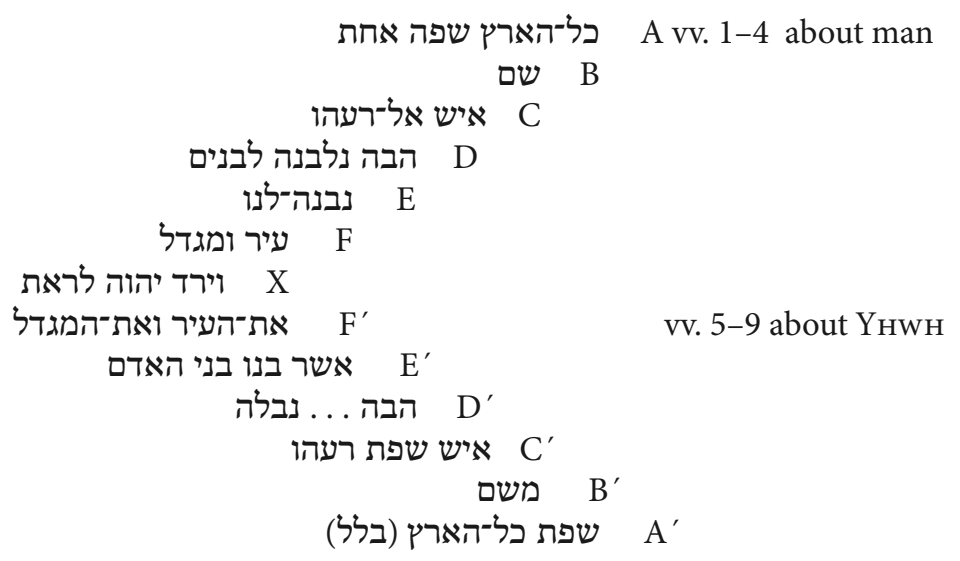

Insofar as this analysis takes into account considerably more of the text than the concentric symmetry above, Fokkelman seems to be on surer ground here. ${ }^{26}$ But we find this concentric symmetry in varying degrees in the two recensions as well. Again, using Fokkelman's notations, the Babel Recension has:

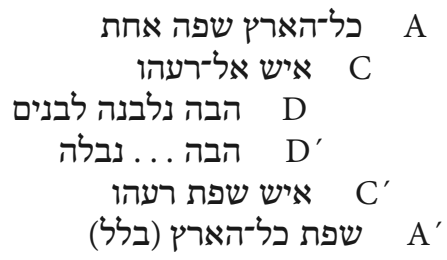

And see the Tower Recension on the next page. Though neither of these chiasms is as full as the one Fokkelman finds in the unified text, both are perfectly acceptable narrative structures. Further, every element of Fokkelman's chiasm is present in exactly one of the two recensions; in no cases is an element in one recension and its chiastic partner in the other. If we assume, for the moment, that these two recen-

${ }^{25}$ Ibid., 22.

${ }^{26}$ Though see the incisive criticism of Fokkelman's proposed chiasm in Gen 11:1-9 by Brettler (Judges, 10-12).

This article was published in JBL 128/2 (2009) 209-24, copyright @ 2009 by the Society of Biblical Literature. To purchase copies of this issue or to subscribe to JBL, please contact SBL Customer Service by phone at 866-727-9955 [toll-free in North America] or 404-727-9498, by fax at 404-727-2419, or visit the online SBL Store at www.sbl-site.org. 
sions did exist, and that both were chiastically structured, the combination thereof would undoubtedly result in a larger chiasm. The redactor, who, being a competent reader, would have seen these chiasms as easily as we do, would presumably have striven to preserve them in his combination of the two independent stories. Fokkelman, then, falls into the same category as Cassuto and Kikawada: he has tried to demonstrate textual unity by pointing out features of narrative artistry that are equally present in Gunkel's independent recensions.

The Tower Recension:

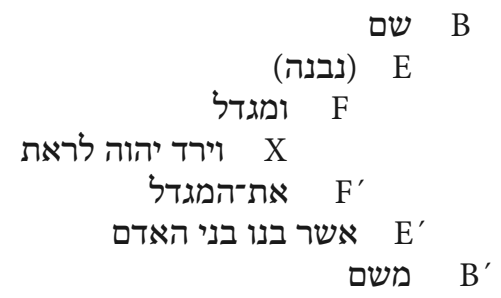

The result of the foregoing analysis is that modern literary critics have failed in this case to achieve their desired effect: to prove the unity of the story of the Tower of Babel. ${ }^{27}$ This does not, however, mean that Gunkel was correct in his division of the text. On the contrary: Gen 11:1-9 is a single, unified literary unit. The two themes of city and tower are stylistically distinct because the author has, as a good literary artist can, linked the various themes of his narrative with specific vocabulary and structural features, such that if one chooses to separate the themes, one also separates the literary features. What Gunkel achieved was in fact to highlight the artistic linking of theme and style on the part of the J author, while, ironically, those literary critics who oppose him have attempted, though perhaps not intentionally, to obscure this narrative technique. The more effective argument against Gunkel's theory is a simple source-critical one. Genesis 11:1-9 shows none of the hallmarks of a composite text: contradictions, doublets, or other narrative inconsistencies. ${ }^{28}$ Gunkel's analysis here, as elsewhere, is overly fragmentary, as was unfortunately typical of source-critical scholarship of that period. It is not a com-

\footnotetext{
${ }^{27}$ The more recent attempts to suggest a composite origin of this passage (see n. 5 above) do disrupt the narrative features noted by Cassuto, Kikawada, and Fokkelman; the literary critics can be said to have succeeded, then, in making a case against some divisions of the text-but not Gunkel's.

${ }^{28}$ Scholars who favor a composite text in Gen 11:1-9 commonly cite two ostensible doublets: the repeated ויהי in vv. 1-2 and the double descent of Yнwн in vv. 5, 7. Neither is in fact problematic. The two uses of represent the two functions of this verb: in v. 1 it is the verbal כל־הארץ predicate to (contra Skinner, Genesis, 224 n. 1), while in v. 2 it introduces a temporal clause. This sequence is attested elsewhere in J (without any suggestion of composite authorship), notably in the very next chapter, Gen 12:10-11. As for the ostensible double descent, in v. 5 YHWH goes down to see what the people have been doing, as he does elsewhere in J (Gen 18:21); upon
}

This article was published in JBL 128/2 (2009) 209-24, copyright @ 2009 by the Society of Biblical Literature. To purchase copies of this issue or to subscribe to JBL, please contact SBL Customer Service by phone at 866-727-9955 [toll-free in North America] or 404-727-9498, by fax at 404-727-2419, or visit the online SBL Store at www.sbl-site.org. 
bination of independent sources that accounts for the dual themes of Gen 11:1-9, but more likely the combination, by the J author or perhaps even before him, of much older independent traditions. Gerhard von Rad's assessment is worth noting: "[Gen 11:1-9] consists of older material which had first to be boldly hewn and recast. . . Y Yet one may not draw literary conclusions from such irregularities (as, for example, the presence of a secondary source to J); our narrator has freely welded single traditions." ${ }^{29}$ One is tempted to think that had Gunkel lived to see the rise of tradition criticism, which of course derived almost entirely from his work, he would have come to this same conclusion.

At issue in this study, then, is not the correctness of Gunkel's theory per se, but rather the method of the modern literary critics who claim to have proven textual unity. We may extrapolate from this situation, where there is no real source-critical issue, to one where there is an authentic need to maintain a textual division. For a brief example, we may take Fokkelman's analysis of Gen 37:18-33. ${ }^{30}$ This passage represents one of the classic cases for source criticism: the factual conflict between accounts of Joseph being stolen by the Midianites and subsequently sold to the Ishmaelites, a conflict that is entirely resolvable by dividing the text. ${ }^{31}$ Fokkelman's discussion of this passage, however, does not even mention this contradiction; he wonders only the following:

Why does Reuben appear twice, and what is the significance of the fact that he finds the pit empty? There is also a striking repetition: the terrible message "a savage beast devoured him" not only occurs in v. 20 , but is repeated verbatim in the middle of v. 33 . What is the point of that? ${ }^{32}$

The solution, for Fokkelman, is chiastic: "Everything falls into place when we discover the structure of vv. 18-33."33

Fokkelman's chiasm is indeed very attractive:

seeing the beginnings of the tower and city, he speaks to his divine council-which in itself suggests that he has returned to the divine realm - and suggests that they descend again and confound the people's speech. On the divine council and the use of the first person plural here and elsewhere in J, see W. Randall Garr, In His Own Image and Likeness: Humanity, Divinity, and Monotheism (Culture and History of the Ancient Near East 15; Leiden: Brill, 2003), 45-83.

${ }^{29}$ Gerhard von Rad, Genesis (OTL; Philadelphia: Westminster, 1972), 148.

${ }^{30}$ Jan Fokkelman, Reading Biblical Narrative: An Introductory Guide (Louisville: Westminster John Knox, 1999), 79-82.

${ }^{31}$ This conflict was central to the discussion of this passage by the rabbinic sages; see Gen. Rab. 84.22; Rashi and Rashbam on Gen 37:28. For a source-critical solution, see Richard E. Friedman, The Bible with Sources Revealed: A New View into the Five Books of Moses (San Francisco: HarperSanFrancisco, 2003), 93-95.

${ }^{32}$ Fokkelman, Reading Biblical Narrative, 79-80.

${ }^{33}$ Ibid., 80.

This article was published in JBL 128/2 (2009) 209-24, copyright @ 2009 by the Society of Biblical Literature. To purchase copies of this issue or to subscribe to JBL, please contact SBL Customer Service by phone at 866-727-9955 [toll-free in North America] or 404-727-9498, by fax at 404-727-2419, or visit the online SBL Store at www.sbl-site.org. 

A
18-20 conspiracy by the brothers: kill Joseph! "A savage beast devoured him!"
B 21-22 speeches by Reuben: no, throw him into the pit
C 23-24 brothers cast Joseph into the pit
D 25 a caravan passes by
X 26-27 proposal by Judah: sell Joseph
$\mathrm{D}^{\prime} \quad 28 \quad$ Joseph sold to caravan
$\mathrm{C}^{\prime} \quad 29 \quad$ Reuben finds the pit empty, rends his clothes
B' $30 \quad$ and mourns; speech to his brothers
A 31-33 they deceive Jacob with the coat, Jacob concludes: Joseph must be dead.
"A savage beast devoured him!"

Though Fokkelman finds significant meaning in this structure, for example, the centrality of Judah's role in the Joseph story, he utterly fails to solve-moreover, he completely ignores-the narrative problem in the passage that is basic to the sourcecritical analysis or, it seems safe to say, to any plain reading of the text. It seems that in his attempt to prove the unity of the text, Fokkelman has privileged structure, that is, verbal and thematic repetitions and echoes, over the simple coherence of the story itself.

"Structural arguments can be and in fact have been used to prove the unity of a given narrative." ${ }^{34}$ Here we get to the heart of the methodological issue: How do we disprove the results of one method, in this case source criticism, by using another, in this case modern literary criticism? It is by no means impossible, but neither is it as straightforward as the literary critics would have us believe. As has been shown above, it is not enough simply to demonstrate that a given block of text has certain literary features. It must also be shown that the individual texts resulting from source criticism, or any other historical-critical method, do not show any of these features. It is this step that has not been taken by those modern literary critics intent on proving textual unity. When applying the results of the literary analysis of a unified text to the constituent elements of a divided text, as was done above, there are three possible outcomes: the feature in question is found in only one of the two recensions, as with Cassuto's "recurring melody" of bet, lamed, and nun; the feature in question is found in both of the recensions, as with Kikawada's discourse analysis; or the feature in question is found in neither recension. Only when the comparison between the canonical and separated texts has been undertaken, and only when the result is the third of these options, can it be said that modern literary criticism has made a case for textual unity. ${ }^{35}$ Even then, however,

\footnotetext{
${ }^{34}$ Shimon Bar-Efrat, "Some Observations on the Analysis of Structure in Biblical Narrative," VT 30 (1980): 154-73, here 172.

${ }^{35}$ Kikawada and Quinn ostensibly take into account the results of source criticism, specifically in their analysis of the flood narrative (Before Abraham Was, 83-106). Yet their refutation
} 
there are caveats: literary-critical arguments about wordplay and structure cannot overshadow or ignore the actual content of the narrative (see Fokkelman's analysis of Genesis 37 above); and the demonstration that a particular source-critical division breaks up a literary structure does not mean that the source-critical enterprise has failed: only that that particular source-critical division may be problematic.

Cassuto's opposition to source criticism was rooted in his a priori belief in the unity, if not the divinity, of the Torah. His biblical analysis was consistently detailed and erudite, taking into account the Near Eastern background of the text, but he was simply prejudiced toward the unity of the text and never really viewed the source-critical approach as a plausible alternative. ${ }^{36}$ Fokkelman, on the other hand, attacks source criticism because it seemingly stands as a barrier to the type of literary criticism he wishes to undertake. ${ }^{37} \mathrm{He}$ states that "'higher' criticism had stubbornly ignored the intersubjective truth that meaning and sense are constituted on the ground where text and reader meet in a process of profound communication with one another that has a mutual effect on both parties." 38 Though he claims to be tolerant of historical criticism as an independent enterprise, ${ }^{39}$ Fokkelman explic-

of the documentary solution does not follow the lines of attack suggested above; rather than examine the individual sources of the flood narrative for signs of literary artistry such as they claim to have found in the canonical text, they are content merely to point out the literary artistry of the final form. Frequently they rely on chiasms, some plausible, others significantly less so (e.g., their discussion of Gen 6:8-9 [p. 86]), and some absolutely without merit (e.g., the proposed chiasm in Gen 7:22-23 [p. 95], which seems to ignore a cluster of words in v. 23, claims "every man" in v. 22 as one element, but "every" and "man" in v. 23 as separate elements, and, most strikingly, seems to be based entirely on the English translation, insofar as it has as its central axis the pronoun "he," which is represented in the Hebrew only by the prefix on the verb "blotted out"which, they argue, constitutes a separate element unto itself!).

${ }^{36}$ See Cassuto's dismissal of source criticism in his book The Documentary Hypothesis and the Composition of the Pentateuch: Eight Lectures (trans. Israel Abrahams; Jerusalem: Magnes, 1961). Note particularly his comment regarding the foundational scholars of the Documentary Hypothesis: "Since we are nearer than they to the spirit of the Bible ... we may perchance ... solve some riddle to which they strove in vain to find a solution" (p. 13).

${ }^{37}$ I focus on Fokkelman in the following discussion, though there are other modern literary critics who have been similarly antagonistic to historical criticism. See especially the strong language of Meir Sternberg, who laments the "over two hundred years of frenzied digging into the Bible's genesis, so senseless as to elicit either laughter or tears" (The Poetics of Biblical Narrative: Ideological Literature and the Drama of Reading [Indiana Studies in Biblical Literature; Bloomington: Indiana University Press, 1985], 13), and see the rebuttal to Sternberg's dismissal of the diachronic perspective by Bernard M. Levinson ("The Right Chorale: From the Poetics to the Hermeneutics of the Hebrew Bible," in "Not in Heaven": Coherence and Complexity in Biblical Narrative [ed. Jason P. Rosenblatt and Joseph C. Sitterson; Indiana Studies in Biblical Literature; Bloomington: Indiana University Press, 1991], 129-53).

${ }^{38}$ Fokkelman, Narrative Art, viii.

${ }^{39}$ Ibid., 2 n. 7: "Diachronic study needs no justification; the origin and transmission of texts are in themselves worthwhile and form an independent object of research." This claim is difficult

This article was published in JBL 128/2 (2009) 209-24, copyright ( 2009 by the Society of Biblical Literature. To purchase copies of this issue or to subscribe to JBL, please contact SBL Customer Service by phone at 866-727-9955 [toll-free in North America] or 404-727-9498, by fax at 404-727-2419, or visit the online SBL Store at www.sbl-site.org. 
itly sets up the showdown between source and literary criticism. First, he argues that if one can show that a text, in this case Gen 11:1-9, exhibits literary features, then this proves the "working hypothesis" that the text is a unity. ${ }^{40}$ It has been shown above that this is not necessarily the case. Moreover, Fokkelman claims that historical criticism is based on "the tacit presupposition that the text is not to be interpreted from itself, because it is stratified or composite, and that to understand it we must first reconstruct its genesis and its process of growth." ${ }^{41}$ This is to denigrate and dismiss the lengthy process by which scholarship arrived at the historicalcritical method, as well as to misrepresent the origins and aims of historical criticism.

Fokkelman makes the methodological distinction between reading the text as an end or as a means. He claims that historical criticism reads the text as a means, whereas his literary approach sees the text as an end. He accuses historical critics of having an underlying belief that the text is not a unity, and he states that "it is necessary that the validity of such an a priori judgment be tested by granting the texts a painstaking and unbiased examination [focused on it as an end]; this is the only equitable treatment one can accord these texts." ${ }^{2}$ Yet this sharp division between the two approaches represents a mistaken view of the history of scholarship. Source criticism did not arise out of a predetermination that the Pentateuch was not a unity; quite the contrary: it came about precisely because of the enormous difficulties encountered in attempts to read the Torah as a coherent, consistent whole; this is why it was called, in its earlier incarnations, "literary criticism." 43 The theories of Wellhausen and others about the religious and intellectual development of the Israelites, which have now unfortunately been so closely linked to the purely textual method of source criticism, do indeed see the text as a means to a historical end. ${ }^{44}$ But the source analysis itself derives from the attempt, and failure, to read the Pentateuch as a unity, because it is riddled with the kinds of narrative contradictions and inconsistencies that Fokkelman glosses over by claiming, rightly or wrongly_or irrelevantly_to have found "structure."

Only after trying and failing to read a text as an end unto itself can we attempt

to square with Fokkelman's insistence on the historical unity of the text as "proven" by modern literary criticism.

${ }^{40}$ Ibid., 12.

${ }^{41}$ Ibid., 4.

${ }^{42}$ Ibid.

${ }^{43}$ See the discussion of this similarity between source and literary criticism in John Barton, "Historical Criticism and Literary Interpretation: Is There Any Common Ground?" in Crossing the Boundaries: Essays in Biblical Studies in Honour of Michael D. Goulder (ed. Stanley E. Porter, Paul M. Joyce, and Davie E. Orton; Biblical Interpretation Series 8; Leiden: Brill, 1994), 3-15, esp. 5-10.

${ }^{44}$ This combination of literary and religious-historical inquiry has been so dominant that the two are now considered one enterprise; hence the statement of Sternberg: "Source-oriented inquiry addresses itself to the biblical world as it really was" (Poetics, 15).

This article was published in JBL 128/2 (2009) 209-24, copyright $\odot 2009$ by the Society of Biblical Literature. To purchase copies of this issue or to subscribe to JBL, please contact SBL Customer Service by phone at 866-727-9955 [toll-free in North America] or 404-727-9498, by fax at 404-727-2419, or visit the online SBL Store at www.sbl-site.org. 
to reconstruct its history; so says Fokkelman. ${ }^{45}$ But this is to commit against source criticism the very crime against which Fokkelman protests when it comes to literary criticism. For Fokkelman, the presumption is that if a text has any literary artistry, it is therefore a unity; more important, the presumption is that the text is a unity. ${ }^{46}$ But neither he nor any of his comrades-in-arms have taken the necessary step to prove this to be the case through a rigorous, evenhanded dialogue with the historical-critical approach. That is the step I have tried to take above in examining the story of the Tower of Babel. Fokkelman has demonstrated literary artistry in the Pentateuch; but he has not demonstrated literary unity.

The question necessarily becomes: Can source criticism and modern literary criticism coexist? The answer is a cautious yes. Both methods begin from the same place: the final form of the text. For source critics, the next step is back in time, to determine how the canonical text came to look as it does. For modern literary critics, the goal is to find a way, through literary-critical means, to understand the final form of the text on its own merits. ${ }^{47}$ There is no inherent conflict here, as the two methods move in absolutely opposite directions. ${ }^{48}$ The conflict, such as it is, comes

\footnotetext{
45 "Not until the interpreter's structural means have been exhausted does the method of genetic explanation seem to me indispensable to an interpretation of texts" (Fokkelman, Narrative Art, 2).

46 "My intuition told me that the narratives from the Hebrew Bible which I knew were more than a patchwork resulting from traditionary and redactional meddling. And second, it was my firm conviction that I would need to trust myself to and surrender to the guidance and manipulation of biblical narrative" (Fokkelman, Narrative Art, vii). This is strikingly and perhaps ironically similar to Wellhausen's famous statement: "[I]n the summer of 1867, I learned through Ritschl that Karl Heinrich Graf placed the Law later than the Prophets, and, almost without knowing his reasons for the hypothesis, I was prepared to accept it" (Julius Wellhausen, Prolegomena to the History of Israel [1883; Scholars Press Reprints and Translations; Atlanta: Scholars Press, 1994], 3). Additionally, both statements are preceded by short accounts of the authors' educational experience and disenchantment with the contemporary standard presentation of biblical scholarship.

${ }^{47}$ The methodology of modern literary criticism is, of course, applicable to both the final and pre-final forms of the text, but though the methodology remains the same across these levels, the results are crucially different. To demonstrate the literary features of the canonical text is knowingly to work with a composite text, at least in those passages that have been demonstrated to be composite. This does not diminish the power of the final form, as is evident from the religious and literary influence of the Bible over the millennia. But it speaks only to how a modern reader, whether in a religious or secular setting, interacts with the text. It has nothing to say about the chronologically earlier levels. Literary criticism of the sources that make up the final form can demonstrate the artistry of a particular author or school of authors and can allow us to say something about the meaning they intended for the text. It is precisely this second application of modern literary criticism that was brought to bear in the analysis of Gunkel's theory on Gen 11:19 above.

${ }^{48}$ This is essentially the point of view espoused (albeit one-sidedly) by David M. Gunn and Danna Nolan Fewell (Narrative in the Hebrew Bible [Oxford Bible Series; Oxford: Oxford University Press, 1993], 11): "We do not think that historical-critical analysis, interesting as it might
}

This article was published in JBL 128/2 (2009) 209-24, copyright ( 2009 by the Society of Biblical Literature. To purchase copies of this issue or to subscribe to JBL, please contact SBL Customer Service by phone at 866-727-9955 [toll-free in North America] or 404-727-9498, by fax at 404-727-2419, or visit the online SBL Store at www.sbl-site.org. 
about when one method is used to address the questions for which the other was intended-that is, when modern literary criticism, the goal of which is to provide the modern reader with the tools to understand and appreciate the difficult canonical text, is applied to the question of the compositional history of the Bible. ${ }^{49}$ The literary-historical background of the final form and the meaning the reader can find in it do not stand in opposition to each other; rather, they are complementary parts of a total reading of the biblical text. John Barton's words of advice to biblical scholars are well worth heeding: "most of the texts they interpret need both historical and literary skill if they are to be adequately interpreted." 50

One may wonder how practitioners of modern literary criticism have come to view their method as exclusive of the historical approach, rather than as one possible way of reading and interpreting the Bible. It may be useful to recognize the parallel developments of other methods, such as form and tradition criticism. The great originators of these methods, Gunkel, von Rad, and Martin Noth, all accepted source criticism as a basic part of biblical criticism; they considered their methods complementary, further explorations of the prehistory of the individual sources. Yet the current incarnations of these subfields take a very different approach, claiming that form and tradition criticism necessarily lead to the obliteration of the Documentary Hypothesis. ${ }^{51}$ Has this happened also with literary criticism? It may be too early to tell, but the difference in approach between Robert Alter, for example, who seems to accept-but recognizes the irrelevance of-the results of source criticism, and Fokkelman, who actively tries to undermine the historical-critical approach, is instructive. ${ }^{52}$

be, is a necessary major precondition of our reading." Gunn and Fewell do not deny the methodology or, necessarily, the results of historical criticism, but, since they are focused explicitly on reading the final form of the text, they have, as they note, "other fish to fry" (p. 12). See also the astute observations of Barton ("Historical Criticism," 4): "The two positions thus do not clash head on, differing about what the text means; they slide past each other without real engagement."

${ }^{49}$ The converse also is generally true: the source-critical deconstruction of the final form of the text should not be claimed as determinative for the "meaning" of the final form (if, in this postmodern intellectual climate, such a thing any longer exists); the canonical text is not interpretable only through the historical-critical lens. Modern literary critics have every right to chafe at such a claim, if and when it is made. See the comments by Gunn and Fewell, Narrative, 8: "[It was assumed that] what was being expounded by the historical critics was, if not the correct meaning of the text, at least a step towards the correct meaning. There are two questions here. One is whether critics (readers) think of texts as having ultimately only a single right meaning. The other is whether critics think that there is a single right method of interpretation." It is fallacious, however, to say that an attitude of objectivity among some source critics condemns the entire sourcecritical enterprise; it condemns only those practitioners who arrogate to themselves the sole right to interpret the canonical text.

${ }^{50}$ Barton, "Historical Criticism," 15.

${ }^{51}$ See prominently Rolf Rendtorff, Das überlieferungsgeschichtliche Problem des Pentateuch (BZAW 147; Berlin: de Gruyter, 1977) and his successors.

${ }^{52}$ See Robert Alter, The Art of Biblical Narrative (New York: Basic, 1981), 20.

This article was published in JBL 128/2 (2009) 209-24, copyright @ 2009 by the Society of Biblical Literature. To purchase copies of this issue or to subscribe to JBL, please contact SBL Customer Service by phone at 866-727-9955 [toll-free in North America] or 404-727-9498, by fax at 404-727-2419, or visit the online SBL Store at www.sbl-site.org. 
Modern literary criticism is a method meant to help us appreciate the Bible as literature; that is, a priori as a unity. Source criticism is meant to explain why, historically, such a reading is so difficult. If, miraculously, an archaeologist were to discover a long-lost copy of the book of J, would this render the modern literary approach obsolete? By no means: modern literary criticism is as unaffected byindeed, is as fundamentally unconcerned with - the history of composition of the Bible as it is by the historical accuracy of the stories related therein. Just as source criticism gives us insight only obliquely into how we can meaningfully read the canonical text as a whole (by helping to point out contradictions, seams, varying viewpoints, etc.- and these can be ignored or explained away by a skillful literary critic), literary criticism is not a tool built for proving or disproving anything about the history of a given text. It is, rather, an important and effective means of helping a reader enter into a deeper and more enriching experience of the text as literature, with all the intellectual and emotional power that literature contains. When these methods are forced into confrontation nothing is accomplished, nothing proven; it is as if we are arguing in different languages: a veritable scholarly Tower of Babel.

This article was published in JBL 128/2 (2009) 209-24, copyright @ 2009 by the Society of Biblical Literature. To purchase copies of this issue or to subscribe to JBL, please contact SBL Customer Service by phone at 866-727-9955 [toll-free in North America] or 404-727-9498, by fax at 404-727-2419, or visit the online SBL Store at www.sbl-site.org. 